\title{
BIODEGRADATION OF ANILINE BY Enterobacter ludwigii KH-A5 ISOLATED FROM THE SOIL AROUND SHIRAZ REFINERY, IRAN
}

\author{
KAFILZADEH F. \\ KHEZRI A.
}

Received: 09/05/2016

Accepted: 05/06/2016

Available online: 26/07/2016
Department of Biology, Jahrom Branch

Islamic Azad University, Jahrom, Iran

\section{ABSTRACT}

Aniline is a harmful substance that pollutes the environment and seriously endangers human health. In the present study five different bacteria were enriched and isolated from the soil around Shiraz refinery (Iran) as aniline degrading bacteria. They were identified as Enterobacter ludwigii $\mathrm{KH}-\mathrm{A} 5$, Raoultella planticola $\mathrm{KH}-\mathrm{A} 2$, Alcaligenes faecalis $\mathrm{KH}-\mathrm{A} 3$, Serratia marcescens $\mathrm{KH}-\mathrm{A} 4$ and Microbacterium barkeri $\mathrm{KH}-\mathrm{A} 1$ based on 16S rDNA gene sequencing. The highest aniline degradation rate (96\%) was observed by $E$. ludwigii $\mathrm{KH}-\mathrm{A} 5$. This strain with the greatest amount of minimum inhibitory concentration (MIC) was the most aniline resistant bacterium. The optimum $\mathrm{pH}$ and temperature that supported biodegradation of aniline by strain $\mathrm{KH}-\mathrm{A} 5$ were 7.0 and $28-35^{\circ} \mathrm{C}$, respectively. The maximum growth and biodegradation of aniline by $\mathrm{KH}-\mathrm{A} 5$ were observed at the initial aniline concentration of $100 \mathrm{mg} \mathrm{l}^{-1}$. The strain could growth on aniline up to concentration of $700 \mathrm{mg} \mathrm{l}^{-1}$ with the degradation rate of $11 \%$. Further studies demonstrated that the addition of $0.5 \mathrm{~g}^{-1}$ glucose or potassium nitrate as a second carbon or nitrogen source could slightly enhance the biodegradation efficiency from $96.0 \%$ to $99.0 \%$. However, even more addition of glucose or potassium nitrate could not further enhance the biodegradation process but delayed the biodegradation of aniline by the strain $\mathrm{KH}-\mathrm{A} 5$. It could be concluded that these new strains, particularly E. ludwigii $\mathrm{KH}-\mathrm{A} 5$, have a potential use for bioremediation of the site contaminated with aniline.

Keywords: aniline, biodegradation, growth, Enterobacter ludwigii KH-A5, Shiraz refinery

\section{Introduction}

Aniline is a widely distributed environmental pollutant resulting from the manufacture of a number of products such as dyes, plastics, resins, pharmaceuticals, petro-chemicals and herbicides (Mohammed et al., 2014; Yen et al., 2008). Aniline has toxicity to life and plant and is considered as an important environmental hazard and is subject to legislative control by the European Economic Community (EEC) directive and in the Priority Pollutant List of US Environmental Protection Agency (Li et al., 2010). This compound is known as the parent molecule in the large family of aromatic amines. Aniline dissolves slowly in water (approx. $35 \mathrm{~g} \mathrm{I}^{-1}$ at $20^{\circ} \mathrm{C}$ ) but quickly dissolves in alcohol, benzene, and organic solvents (SCOEL/SUM/153 2010; Sihtmae et al., 2010). It was revealed that the soil microorganisms while adaptation, to immediate environment developed certain metabolic pathways for effective utilization of synthetic compounds (Obinna et al., 2008). Aniline is a major breakdown product of diphenylamine and p-aminoazobenzene (Zissi et al., 1997). To treat wastewaters and affected soils 
containing aniline and most of its derivatives, remedies often used are photodecomposition, auto-oxidation, electrolysis, resin adsorption or ozone oxidation but the cost of such treatments limits their application to small scale facilities (Ahmed et al., 2010). Microbial degradation leading to different altered end products is thought to be the main mechanisms of toxic aniline elimination from the environment (Obinna et al., 2008). Numbers of reports concerning the bacterial degradation of aniline had already been published, such as Corynebacterium sp. (Ahmed et al., 2013), Candida tropicalis AN (Wang et al., 2011), Delftia sp. (Liu et al., 2002; Zhang et al., 2008; Liang et al., 2005) Pseudomonas sp. (Meyers 1999; Fukumori and Saint 1997; Bathe 2004) and Acinetobacter sp. (Takeo et al., 1998; Fujii et al., 1997). Li et al. (2007) isolated strain PN1001, which is a member of the Pseudomonas species and it was capable of degrading pentylamine and aniline. Liu et al. (2002) isolated a bacterial strain, AN3, which was able to use aniline as sole carbon and nitrogen source from activated sludge and identified it as Delftia sp. AN3. This strain was capable of growing in concentrations of aniline up to $5000 \mathrm{mg} \mathrm{l}^{\mathrm{l}^{-1}}$. O'Neill et al., (2000) isolated a consortium of bacteria capable of degrading aniline found in wastewaters produced by oil fields, in marine mud and in acid peat bog water and soils.

In the present study, aniline degrading bacteria were isolated from the soil around Shiraz refinery, Iran and identified by physiological and biochemical tests and 16S rDNA gene sequencing. HPLC analysis and MIC test were used to determine aniline biodegradation rate and the most resistant isolated strain, respectively. Furthermore, growth rate and optimum physicochemical parameters for efficient degradation of aniline by superior strain were surveyed.

\section{Materials and methods}

\subsection{Soil sampling}

Sampling of soil around Shiraz Refinery, Iran (located at $30^{\circ} 29^{`}$ east latitude and $52^{\circ} 22^{`}$ north longitude) was done in autumn year 2012, from three stations and each station 3 times. Soil sampling depth was 3 to $5 \mathrm{~cm}$ and done by sterile containers and were transported to the laboratory within 3 hours in ice containers.

\subsection{Enrichment and isolation of bacteria}

Enrichment was performed using a basal salt medium (BSM) containing (per liter) $\mathrm{MgSO}_{4} .7 \mathrm{H}_{2} \mathrm{O}$ (CAS 10034-998) (0.5 g), $\left(\mathrm{NH}_{4}\right)_{2} \mathrm{SO}_{4}$ (CAS 7783-20-2) (0.5 g), $\mathrm{K}_{2} \mathrm{HPO}_{4}$ (CAS 7758-11-4) (0.5 g), FeCl. $\mathrm{H}_{2} \mathrm{O}$ (CAS 24290-40-2) (10 mg), $\mathrm{CaCl}_{2} \cdot \mathrm{H}_{2} \mathrm{O}$ (CAS 13477-29-7) $\left(10 \mathrm{mg}\right.$ ), $\mathrm{MnCl}_{2}$ (CAS 7773-01-5) $(0.1 \mathrm{mg}), \mathrm{ZnSO}_{4}$ (CAS 7733-02-0) (0.01 mg) and sodium citrate (CAS 68-04-2) (0.01 mg). $95 \mathrm{ml}$ of BSM containing $0.1 \mathrm{~g} \mathrm{l}^{-1}$ of aniline (CAS 62-53-3) was mixed with 10 grams of soil sample. The $\mathrm{pH}$ of the medium was adjusted to 7.0. Cultures were incubated aerobically on a reciprocal shaker $(100 \mathrm{rpm})$ at room temperature $\left(23-25^{\circ} \mathrm{C}\right)$ in the dark to preclude photolysis reactions. All enrichment cultures were subcultured on the same medium at a one week interval. From a one week-old culture, $10 \mathrm{ml}$ was transferred to $90 \mathrm{ml}$ of freshly prepared aniline medium. Repeat the transfer process said above every week. After two months enrichment, the liquid medium was plated on solid culture medium and cultured at 30 ${ }^{\circ} \mathrm{C}$. Morphologically distinct colonies were selected for plate clearance assay (Kafilzadeh and Farhadi, 2015).

\subsection{Identification of aniline degrading bacteria}

The isolated strains were identified by colony morphology, Gram staining, microscopic form and some biochemical tests including oxidase, catalase, triple sugar iron (TSI), urease, citrate, lactate dehydrogenase (LD), methyl red (MR), Voges-Proskauer (VP) and sulfur indole motility (SIM) (Holt et al. 1994).

\subsection{The $16 S$ rDNA gene sequencing}

In order to confirm the results obtained from the biochemical and morphological tests molecular identification was done by of 165 rDNA gene sequencing. DNA extraction was done with the CinnaGen company kit program (DNP kit, CinnaGen, Iran). For PCR amplification, two universal primers for the Domain Bacteria, 27F 5'- 
AGAGTTTGATCMTGGCTCAG-3' and 338R 5'-GCTGCCTCCCGTAGGAGT-3' were used as sense and antisense primers, respectively (Suzuki and Giovannoni, 1996). The reaction mixture was prepared to a total volume of 25 $\mu \mathrm{l}$ containing: $1 \mu \mathrm{l}$ dNTP, $10 \mu \mathrm{l} \mathrm{MgCl} 2,10 x$ PCR buffer, $5 \mu$ of each primers, $2 \mu \mathrm{l}$ template DNA, $2 \mu \mathrm{l}$ Taq polymerase. The reaction mixture was incubated in a thermal cycler with an initial denaturation step at $94^{\circ} \mathrm{C}$ for 4 minutes, followed by 30 cycles of denaturation at $94{ }^{\circ} \mathrm{C}$ for 45 seconds, annealing at $56{ }^{\circ} \mathrm{C}$ for 45 seconds and extension at $65{ }^{\circ} \mathrm{C}$ for 40 seconds and a final extension step at $72{ }^{\circ} \mathrm{C}$ for 10 minutes. PCR product was analyzed in 1\% agarose gel (CAS 9012-36-6) stained with ethidium bromide. Gels were photographed by Gel Doc system. DNA sequences of the cloned 16S rDNA fragments compared using BLAST at http://www.ncbi.nlm.nih.gov/BLAST/ (National Center of Biotechnology Infor-mation, NCBI).

\subsection{Biodegradation experiments}

Aniline degradation experiments were conducted in $250 \mathrm{ml}$ Erlenmeyer flasks containing $100 \mathrm{ml}$ of BS medium. Aniline was added to BS liquid media to final concentration of $100 \mathrm{mg} \mathrm{l}^{-1}$. Bacteria strains $\left(10^{6} \mathrm{cells} \mathrm{ml}^{-1}\right)$ was incubated overnight $(\sim 14 \mathrm{~h})$ in $5 \mathrm{ml}$ nutrient broth at $30^{\circ} \mathrm{C}$. After incubation, cultures were centrifuged at 6000 rpm for $15 \mathrm{~min}$ and cells collected. These were washed three times with BS liquid medium and resuspended in a small volume $(5 \mathrm{ml})$ of the same medium. Inocula for all experiments were prepared by diluting the recovered cultures with desired media to give a spectrophotometric reading of 0.05 at $600 \mathrm{~nm}$. Cell suspension $(500 \mu \mathrm{l})$ was inoculated into a $100 \mathrm{ml} \mathrm{BS}$. The cultures were incubated on orbital shaker at $150 \mathrm{rpm}$ at $30{ }^{\circ} \mathrm{C}$ for 7 days. At 24 h interval, $20 \mathrm{ml}$ of each culture were sampled for chromatographic analyses. Controls involving the use of uninoculated flasks were included and each experiment was performed in triplicate (Weaver et al. 1994; Kafilzadeh and Farhadi, 2015).

\subsection{Extraction and determination of aniline}

Two $\mathrm{ml}$ of methanol (CAS 67-56-1) were added to $5 \mathrm{ml} \mathrm{BS}$ medium in screw cap glass tubes that were than shaken several times. One $\mathrm{ml}$ of the upper phases (methanol) were transferred to clean tubes and evaporated on a rotary evaporator. The remaining pellets were dissolved in $2 \mathrm{ml}$ of HPLC mobile phase and stored at $4{ }^{\circ} \mathrm{C}$ for HPLC analysis. Ten $\mu \mathrm{l}$ of each sample were injected into a Shimadzu HPLC system equipped with UV detector at a fixed wavelength $254 \mathrm{~nm}$. The analysis was carried out by using a C18 column. Methanol: water (80:20 v/v) was used as a mobile phase at a flow rate of $0.5 \mathrm{ml} \mathrm{min}^{-1}$ (Weaver et al. 1994; Kafilzadeh and Farhadi, 2015).

\subsection{The minimum inhibitory concentration test (MIC)}

MIC test was used to determine the most resistant isolated bacteria to aniline which is the minimum concentration of aniline that inhibit the growth of bacteria. First, the bacterial suspensions were prepared in LB Broth medium. Then for each bacterium, 10 tubes containing $5 \mathrm{ml}$ basal medium (MS) was considered, then autoclaved and each of the concentrations of $0.1,0.2,0.3,0.4,0.5,0.6,0.7,0.8,0.9$ and $1 \mathrm{gl}^{-1}$ of aniline were added to each tubes. At the end $0.1 \mathrm{ml}$ of the prepared suspension was added to the tubes and incubated at 30 ${ }^{\circ} \mathrm{C}$ for 48 hours. The turbidity was then measured in each of the tubes. The first tube with no turbidity showed the MIC value. According to the results, the best aniline degrading bacterium and the most resistant bacterium to aniline (strain $\mathrm{KH}-\mathrm{A} 5$ ) was selected for further analysis.

\subsection{Effect of initial aniline concentration on the biodegradation and growth of strain $\mathrm{KH}-\mathrm{A5}$}

The culture of strain $\mathrm{KH}-\mathrm{A} 5$ was prepared and adjusted to an optical density at $600 \mathrm{~nm}\left(\mathrm{OD}_{600}\right)$ of 1.0 , then the final density of $10^{6}$ cells $\mathrm{l}^{-1}$ inoculums were inoculated into the flasks containing BS media with aniline as sole carbon source. The range of aniline concentrations was increased from 10 to $800 \mathrm{mg} \mathrm{l}^{-1}$. The flasks were incubated at $30^{\circ} \mathrm{C}$ with $180 \mathrm{rpm}$ for 7 days. Samples were collected periodically to measure the biomass and the aniline degradation. The biomass contents were monitored spectrophotometrically by measuring absorbance at $600 \mathrm{~nm}$. 


\subsection{Effect of initial $\mathrm{pH}$ on the biodegradation of aniline by the strain $\mathrm{KH}-\mathrm{A5}$}

The effect of initial $\mathrm{pH}$ on the biodegradation of aniline by the strain $\mathrm{KH}-\mathrm{A} 5$ was also studied in $250 \mathrm{ml}$ conical flasks. Ten $\mathrm{ml}$ of strain $\mathrm{KH}-\mathrm{A} 5$ culture was inoculated into flasks containing $90 \mathrm{~mL} \mathrm{BS}$ medium with the presence of $100 \mathrm{mg} \mathrm{l}^{-1}$ aniline to give the final KH-A5 density of $10^{6} \mathrm{cells} \mathrm{ml}^{-1}$. The $\mathrm{pH}$ values of medium were then adjusted to 5.0, 6.0, 7.0, 8.0 and 9.0, respectively, using $2 \mathrm{~mol} \mathrm{I}^{-1} \mathrm{H}_{2} \mathrm{SO}_{4}$ (CAS 7664-93-9) or $2 \mathrm{~mol} \mathrm{I}^{-1} \mathrm{NaOH}$ (CAS 1310-732). These flasks were then shaken on a rotary shaker at $180 \mathrm{rpm}$ and $30^{\circ} \mathrm{C}$. Samples were also collected from each flask at $24 \mathrm{~h}$ intervals and centrifuged at $6000 \mathrm{rpm}$ for $15 \mathrm{~min}$ before being subjected to determine the aniline concentration.

\subsection{Effect of temperature on the biodegradation of aniline by the strain KH-A5}

Strain $\mathrm{KH}-\mathrm{A} 5$ culture of $10 \mathrm{ml}$ was inoculated into $250 \mathrm{~mL}$ conical flasks containing $90 \mathrm{ml} \mathrm{BS}$ medium with the presence of $100 \mathrm{mg} \mathrm{l}^{-1}$ aniline to give the final $\mathrm{KH}-\mathrm{A} 5$ density of $10^{6}$ cells $\mathrm{ml}^{-1}$. The $\mathrm{pH}$ values of medium were adjusted to 7.0 using $2 \mathrm{~mol} \mathrm{I}^{-1} \mathrm{H}_{2} \mathrm{SO}_{4}$ or $2 \mathrm{~mol} \mathrm{I}^{-1} \mathrm{NaOH}$. Then these flasks were shaken on rotary shakers at 180 rpm and five different temperatures, i.e., $15,20,25,28$ and $35^{\circ} \mathrm{C}$, respectively. Samples collection and treatment procedures were the same as before.

\subsection{Effect of second carbon or nitrogen sources on the biodegradation of aniline by the strain KH-A5}

To study the effect of second carbon or nitrogen sources on the degradation of aniline, different dosages $(0.5$, 1.5 , and $3 \mathrm{~g} \mathrm{I}^{-1}$ ) of glucose (CAS 50-99-7) as a second carbon source as well as different dosages (0.5, 1.5, and $3 \mathrm{~g} \mathrm{l}^{-1}$ ) of potassium nitrate (CAS 7757-79-1) as a nitrogen source were added into the flasks containing $90 \mathrm{ml} \mathrm{BS}$ medium, $10 \mathrm{ml}$ strain $\mathrm{KH}-\mathrm{A} 5$ culture and $100 \mathrm{mg} \mathrm{l}^{-1}$ of aniline. Only aniline added as sole carbon and nitrogen source was set as control. The $\mathrm{pH}$ values of medium were adjusted to $\mathrm{pH} 7.0$ using $2 \mathrm{~mol} \mathrm{I}^{-1} \mathrm{H}_{2} \mathrm{SO}_{4}$ or $2 \mathrm{~mol} \mathrm{I}^{-1}$ $\mathrm{NaOH}$ and incubated on a rotary shaker at $180 \mathrm{rpm}$ and $30^{\circ} \mathrm{C}$.

\section{Results}

\subsection{Identification of aniline degrading bacteria}

The results obtained from morphological and biochemical tests are shown in table 1. Five bacteria were identified including Enterobacter ludwigii, Raoultella planticola, Alcaligenes faecalis, Serratia marcescens and Microbacterium barkeri.

Table 1. The results of morphological and biochemical tests

\begin{tabular}{|c|c|c|c|c|c|c|c|c|c|c|c|c|}
\hline Bacteria & Gram & Shape & Motility & $\mathrm{H}_{2} \mathrm{~S}$ & Citrate & OD & LD & Urease & Indole & Catalase & Oxidase & VP \\
\hline E. ludwigii & - & Rod & + & - & + & + & + & - & - & + & - & + \\
\hline R. planticola & - & Rod & - & - & + & - & + & + & - & + & - & + \\
\hline $\begin{array}{c}S . \\
\text { marcescens }\end{array}$ & - & Rod & + & + & + & + & + & - & - & + & - & + \\
\hline M. barkeri & + & Rod & + & - & + & - & - & - & - & + & - & - \\
\hline A. faecalis & - & Rod & + & + & + & - & - & + & - & + & + & + \\
\hline
\end{tabular}

The sequences of $16 \mathrm{~S}$ rDNA of isolated bacteria were compared with sequence of registered bacteria from the GenBank. The homology between sequences obtained from 16S rDNA and gene bank showed E. ludwigii with $98 \%$ similarity, S. marcescens with $99 \%$ similarity, A. faecalis with $99 \%$ similarity, R. planticola with $98 \%$ similarity and $M$. barkeri with $97 \%$ similarity.

The $16 \mathrm{~S}$ rDNA gene for these bacteria were registered in the NCBI GenBank, and their accession numbers were as E. Iudwigii strain KH-A5 Accession: KF366298.1, S. marcescens strain KH-A4 Acceession: KF366297.1, A. faecalis 
strain KH-A3 Accession: KF366296.1, R. planticola strain KH-A2 Accession: KF366295.1, M. barkeri strain KH-A1 Accession: KF366294.1.

\subsection{Biodegradation and determination of aniline}

Results from HPLC analysis indicated that aniline was considerably degraded by the bacterial isolates. The highest aniline degradation rate (96\%) was observed by E. ludwigii KH-A5 followed by S. marcescens $\mathrm{KH}-\mathrm{A} 4$ (78\%), $M$. barkeri $\mathrm{KH}-\mathrm{A} 1$ (75\%), R. planticola $\mathrm{KH}-\mathrm{A} 2$ (70\%) and A. faecalis $\mathrm{KH}-\mathrm{A} 3$ (64\%). The biodegradation capability of the strain $\mathrm{KH}-\mathrm{A} 5$ for aniline was remarkably higher than other strains. Results are graphically presented in Fig. 1.

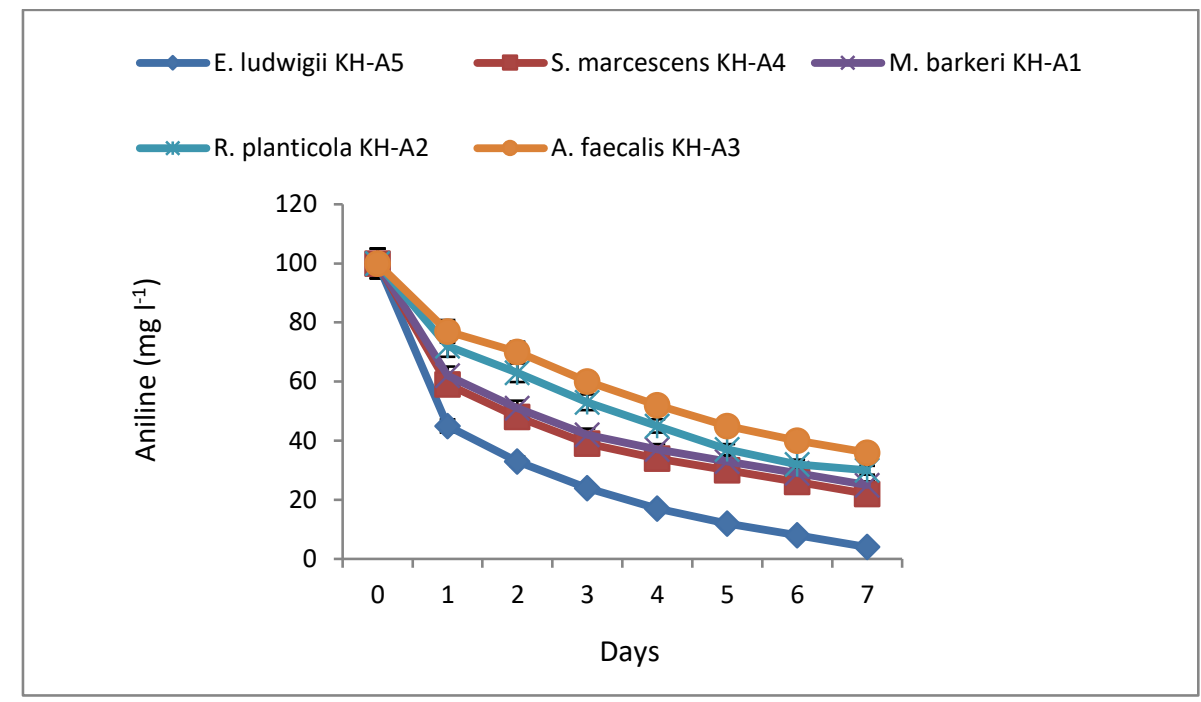

Figure 1. Degradation of aniline by bacteria at $30{ }^{\circ} \mathrm{C}$

\subsection{MIC test}

The MIC tests results of the various aniline concentrations indicated $E$. ludwigii $\mathrm{KH}-\mathrm{A} 5$ as the most resistant bacterium. It follows with $S$. marcescens $\mathrm{KH}-\mathrm{A} 4, \mathrm{M}$. barkeri $\mathrm{KH}-\mathrm{A} 1, R$. planticola $\mathrm{KH}-\mathrm{A} 2$ and $A$. faecalis $\mathrm{KH}-\mathrm{A} 3$, respectively (Table 2 ).

Table 2. Results of MIC test at $30^{\circ} \mathrm{C}$

\begin{tabular}{ccccccccccccccc}
\hline & \multicolumn{10}{c}{ Concentration $\left(\mathrm{g} \mathrm{l}^{-1}\right)$} \\
Bacteria & 1 & 0.9 & 0.8 & 0.7 & 0.6 & 0.5 & 0.4 & 0.3 & 0.2 & 0.1 & $\begin{array}{c}\text { Test \& } \\
\text { Bacteria }\end{array}$ & $\begin{array}{c}\text { Test \& } \\
\text { Aniline }\end{array}$ \\
\hline E. ludwigii & - & - & - & + & + & + & + & + & + & + & + & - \\
\hline S. marcescens & - & - & - & - & - & + & + & + & + & + & + & - \\
\hline M. barkeri & - & - & - & - & - & + & + & + & + & + & + & - \\
\hline R. planticola & - & - & - & - & - & - & - & + & + & + & + & - \\
\hline A. faecalis & - & - & - & - & - & - & - & + & + & + & + & - \\
\hline
\end{tabular}

\subsection{Effect of initial aniline concentration on the biodegradation and growth of strain $\mathrm{KH}-5$}

The strain KH-A5 could degrade 59, 77, 96, 71, 53, 40,31, 19 and $11 \%$ of aniline at the initial aniline concentrations of $10,50,100,200,300,400,500,600$ and $700 \mathrm{mg} \mathrm{l}^{-1}$, respectively. The maximum growth and biodegradation of aniline were observed at the initial aniline concentration of $100 \mathrm{mg} \mathrm{l}^{-1}$. There was no growth when the initial aniline concentration was higher than $700 \mathrm{mg} \mathrm{l}^{-1}$. The strain could growth on aniline up to concentration of $700 \mathrm{mg} \mathrm{l}^{-1}$ with the degradation rate of $11 \%$ (Fig 2). 


\subsection{Effect of initial $\mathrm{pH}$ on the biodegradation of aniline by the strain $\mathrm{KH}-\mathrm{A5}$}

The strain $\mathrm{KH}-\mathrm{A} 5$ could degrade more than $50 \%$ of aniline in a range of $\mathrm{pH}$ levels between 6.0 to 8.0. The optimum $\mathrm{pH}$ for biodegradation of aniline by $\mathrm{KH}-\mathrm{A} 5$ was found to be 7.0. Aniline biodegradation was significantly reduced at a $\mathrm{pH} 5$ and 9 (Fig. 3).

\subsection{Effect of temperature on the biodegradation of aniline by the strain $\mathrm{KH}-\mathrm{A5}$}

As shown in Fig. 4, the optimum temperature for growth of the strain KH-A5 was between 28 and $35{ }^{\circ} \mathrm{C}$. Aniline biodegradation efficiency was the fastest at this temperature range as aniline concentration decreased from 100 $\mathrm{mg} \mathrm{l}^{-1}$ to $4 \mathrm{mg} \mathrm{l}^{-1}$ within 7 days. However, aniline biodegradation efficiency was dramatically decreased when the temperature dropped to 20 and $15^{\circ} \mathrm{C}$.

\subsection{Effect of second carbon or nitrogen sources on the biodegradation of aniline by the strain KH-A5}

As shown in Fig. 5, the aniline degradation efficiency could reach as high as $96.0 \%$ within 7 days when only aniline was added as a sole carbon source.

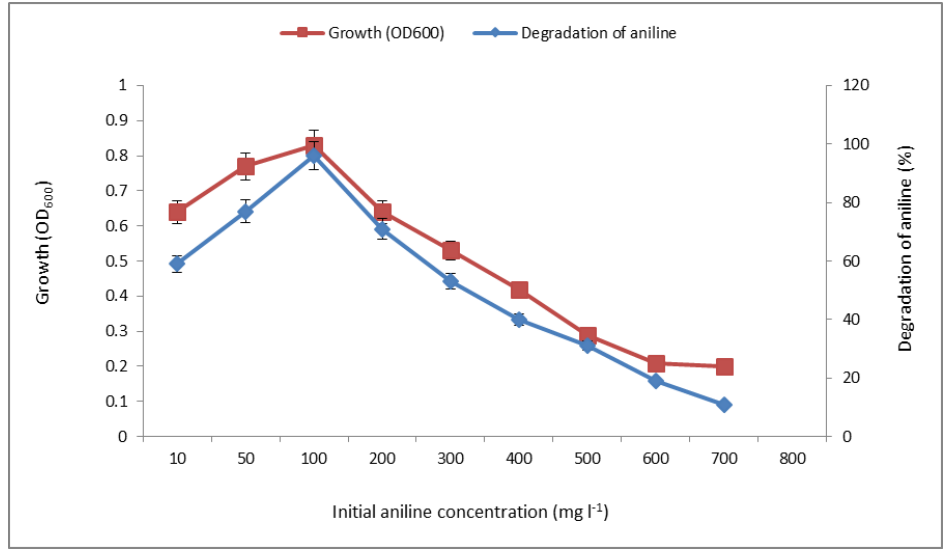

Figure 2. Profile of cell growth and aniline degradation at various initial concentrations of aniline by strain $\mathrm{KH}-\mathrm{A} 5$ at $30{ }^{\circ} \mathrm{C}$

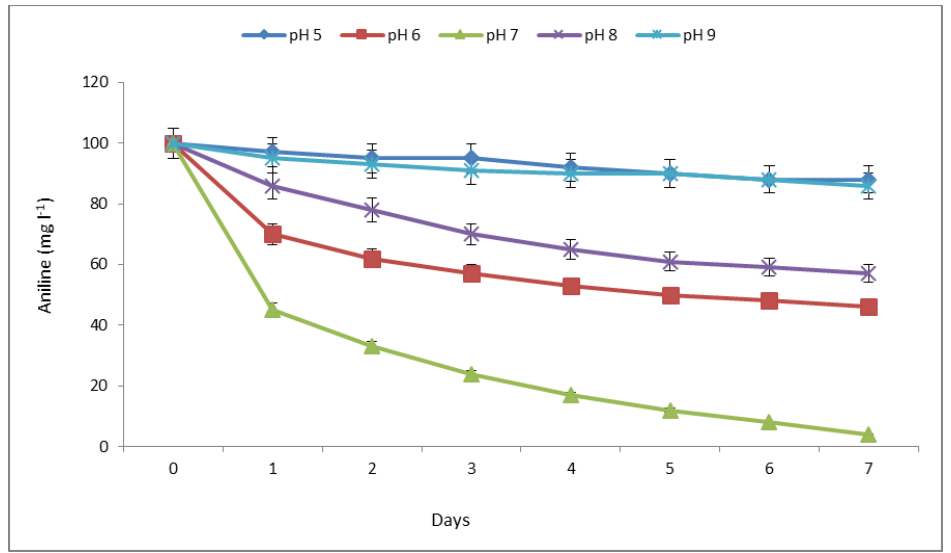

Figure 3. Effect of initial $\mathrm{pH}$ on the biodegradation of aniline by strain $\mathrm{KH}-\mathrm{A} 5$ at $30^{\circ} \mathrm{C}$

After adding $0.5 \mathrm{~g} \mathrm{l}^{-1}$ glucose as the second carbon source, the aniline degradation efficiency was slightly increased by $3.0 \%$ within the same period. However, when more than $0.5 \mathrm{~g} \mathrm{l}^{-1}$ glucose was added, the aniline 
degradation efficiency within the same period even decreased drastically. The same phenomenon could also be observed in the tests of adding potassium nitrate as a second nitrogen source (Fig. 6).

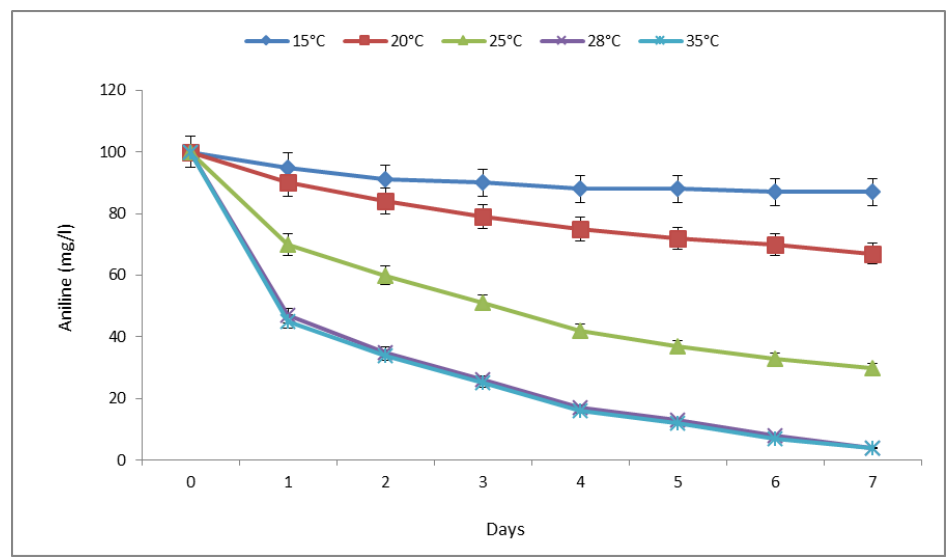

Figure 4. Effect of temperature on the biodegradation of aniline by strain $\mathrm{KH}-\mathrm{A} 5$ at $\mathrm{pH} 7.0$

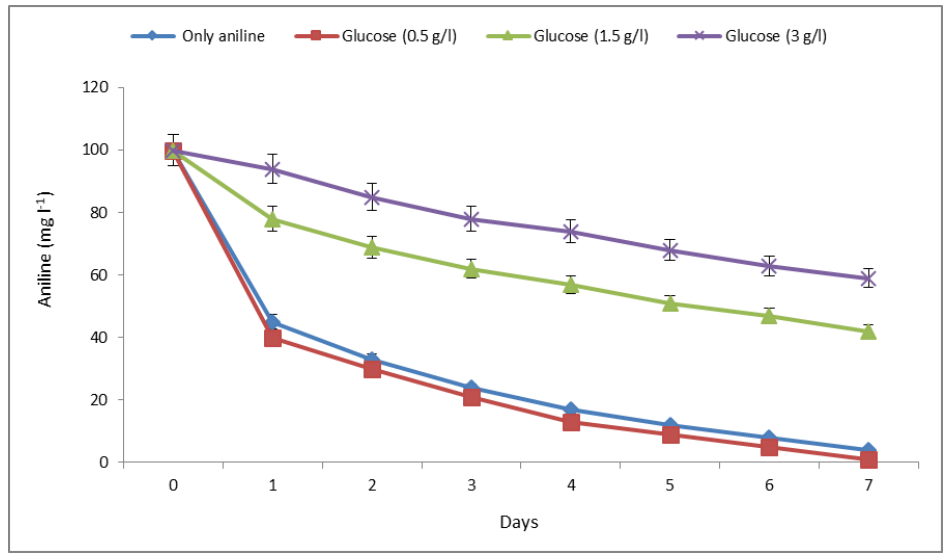

Figure 5. Effect of different doses of glucose as second carbon on the biodegradation of aniline by strain $\mathrm{KH}-\mathrm{A} 5$ at $30^{\circ} \mathrm{C}$ and $\mathrm{pH} 7.0$

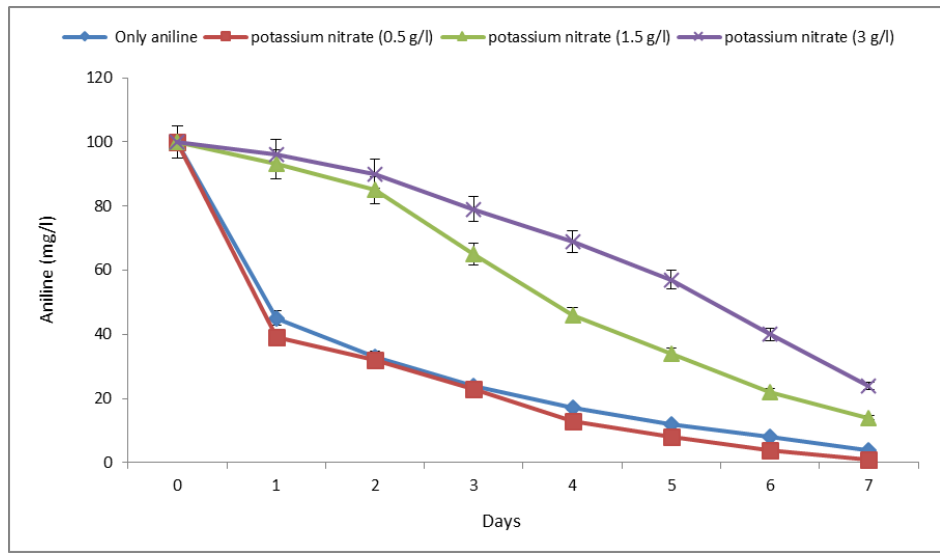

Figure 6: Effect of different doses of potassium nitrate as second nitrogen on the biodegradation of aniline by strain $\mathrm{KH}-\mathrm{A} 5$ at $30^{\circ} \mathrm{C}$ and $\mathrm{pH} 7.0$ 


\section{Discussion}

Aromatic compounds are one of the major groups of xenobiotic compounds. Many of these chemicals are persistent, toxic to life forms, and act as stressors. Bacteria are constantly exposed to biotic and abiotic cues, and one such cue is aromatic compounds. One such aromatic compound, aniline, is degraded by different groups of bacteria (Mohammed et al., 2014; Maurice et al., 2013). In the present work, the soil around Shiraz refinery was sampled in autumn year 2012. The colonies of bacteria appeared in the aniline agar medium within 3 to 5 days. It indicates their ability to use aniline as the sole carbon and energy sources. Aniline degrading bacteria were identified via usual biochemical tests and PCR method with 16S rDNA gene sequencing. Obinna et al. (2008) identified two strains of Rhodococcus isolated from the tropical ecosystem contaminated with aniline, which utilized aniline as carbon resource. Li et al. (2010) identified strain HSA6 as Erwinia amylovora on the basis of 16S rDNA sequence and morphological and physiological characteristics which was capable of aniline degradation. No Rhodococcus and Erwinia were found in the current research.

In the present study, different bacteria were used for aniline degradation with varying degrading ability. It was found that the highest degradation rate (96\%) was shown by $E$. ludwigii KH-A5 which may be due to favor able environmental conditions as well as high production of enzymes responsible for aniline biodegradation. Ahmed et al. (2010) identified strain ST1 as Staphylococcus aureus which was capable of degrading $59.65 \%$ of aniline after 72 h. Wang et al. (2007) isolated strain Pseudomonas sp. from activated sludge obtained from a Northeastern China treatment facility for petrochemical wastewater which was capable of degrading $89 \%$ of aniline after $24 \mathrm{~h}$ at a concentration ranging between 150 and $200 \mathrm{mg} \mathrm{l}^{-1}$. Ahmed et al., (2013) isolated Corynebacterium sp. from soil Tahwhay-Monifia (Egypt) which was capable of degrading $30 \%$ aniline within 24 h. Xiao et al. (2009) isolated Delftia sp. XYJ6 that was capable to degrade aniline at rate $100 \%$ within 22 h. No Pseudomonas, Staphylococcus or Corynebacterium was found in the current research. During the initial step of cultivation, a sudden drop of aniline level was observed. As demonstrated in figure 1, this rapid decrease of aniline concentration in the medium was due to either its assimilation by bacteria or adsorption onto the cell wall.

In the present research, MIC test was used to determine the most resistant isolated bacteria to aniline. The results indicated that the most resistant bacterium belonged to $E$. ludwigii $\mathrm{KH}-\mathrm{A} 5$ with $\mathrm{MIC}$ of $0.7 \mathrm{~g} \mathrm{I}^{-1}$. Moreover, no growth could be observed at the concentrations greater than $0.7 \mathrm{~g} \mathrm{I}^{-1}$. It can be concluded that high concentrations of aniline inhibit the growth of bacteria. Kafilzadeh et al. (2013) showed that aniline degradation by isolates was considerable and the Pseudoalteromonas arctica was the most resistant bacterium with MIC of $0.2 \mathrm{~g} \mathrm{l}^{-1}$. Therefore, the tolerance rate of this bacterium to aniline was less than isolated bacteria in the current study. Tolerant bacteria may utilize aniline as source of carbon and energy for their growth and reproduction; furthermore, bacterial metabolism releases enzymes such as glutamine synthetase and aniline dioxygenase, by which aniline is oxidized and consequently, transformed or degraded to less toxic compounds (Arora, 2015).

In the current study, the aniline degradation characteristics and biomass of E. ludwigii $\mathrm{KH}-\mathrm{A} 5$ at various initial concentrations of aniline (10-700 $\left.\mathrm{mg}^{-1}\right)$ were determined by monitoring aniline concentration and cell growth at $\mathrm{OD}_{600}$ periodically. An inhibitory effect showed that the biomass growth and the degradation of aniline were declined with the elevated initial aniline concentration higher than $100 \mathrm{mg} \mathrm{l}^{-1}$. These results was also supported by Li et al. (2010), whose isolated Erwinia sp. strain HSA6 from activated sludge that was capable of degrading $100 \%$ of aniline at $0.5 \mathrm{~g}$ I aniline concentration after $24 \mathrm{~h}$ culture. The degradation rate of aniline was found to descend as the concentration of aniline increased from 0.5 to $3 \mathrm{~g} \mathrm{l}^{-1}$. The growth of strain HSA6 also appeared to decrease with an increase in aniline concentration. Aoki et al. (1983) demonstrated that growth of Rhodococcus erythropolis AN-13 was strongly inhibited by aniline at concentrations greater than $3.3 \mathrm{~g} \mathrm{l}^{-1}$. Decrease in the tolerance rate at higher concentration may be due to toxic effects of aniline with regard to inadequate cell/aniline ratio or biomass through the inhibition of metabolic activity. Similar results were observed in various reported microorganisms (Sarwade and Gawai, 2014). 
In the current study, effect of initial $\mathrm{pH}$ and temperature on the biodegradation of aniline by the strain $\mathrm{KH}-\mathrm{A} 5$ was investigated. Aniline concentration was dropped from 100 to $4.0 \mathrm{mg} \mathrm{l}^{-1}$ within 7 days especially at $\mathrm{pH} 7.0$, which mean that the biodegradation efficiency could reach as high as $96 \%$. The results are consistent with previous studies which have found that most degrading bacteria, such as Candida tropicalis AN1 (Wang et al., 2011) and Frateuria (Murakumi et al., 1999), could degrade aniline at a narrow pH range of 6.0 and 8.0. Degradation of aniline also reached the maximal values at a range of temperature levels between 28 to $35^{\circ} \mathrm{C}$. On the contrary, the aniline degradation declined sharply when the temperature dropped to $20{ }^{\circ} \mathrm{C}$ and under, indicating that the lower temperature is not beneficial for the biodegradation of aniline by the strain $\mathrm{KH}-\mathrm{A} 5$. These growth conditions of $\mathrm{E}$. ludwigii $\mathrm{KH}-\mathrm{A} 5$ for aniline degradation were similar those of other bacteria reported previously (Wang et al., 2011; Sarwade and Gawai, 2014).

In the present work, the effect of glucose as a second carbon source or potassium nitrate as a second nitrogen source on the biodegradation of aniline by the strain $\mathrm{KH}-\mathrm{A} 5$ was also investigated. The results indicated that the addition of $0.5 \mathrm{~g} \mathrm{l}^{-1}$ glucose or potassium nitrate as a second carbon or nitrogen source could slightly enhance the biodegradation efficiency from $96.0 \%$ to $99.0 \%$. However, even more addition of glucose or potassium nitrate could not further enhance the biodegradation process but delayed the biodegradation of aniline by the strain $\mathrm{KH}-\mathrm{A} 5$. The enhanced degradation of aniline was due to the fact that extra glucose or potassium nitrate could be co-metabolized as a second carbon or nitrogen source to enhance the growth of KH-A5. However, when an excessive second carbon or nitrogen source was present, the degradation of aniline was suppressed since glucose and potassium nitrate could be more easily assimilated than aniline by microorganisms (Jian and Chunjuan, 2007).

\section{Conclusions}

Five aniline degrading bacterial strains were isolated from the soil around Shiraz Refinery, Iran.

The results show with MIC increase, also increases biodegradation rate. So that $E$. ludwigii $\mathrm{KH}-\mathrm{A} 5$ has the most degradation rate with the highest MIC. But $R$. planticola $\mathrm{KH}-\mathrm{A} 2$ and $A$. faecalis $\mathrm{KH}-\mathrm{A} 3$ had the least degradation rate with the lowest MIC. The optimal $\mathrm{pH}$ and temperature range for the biodegradation of aniline by $\mathrm{KH}-\mathrm{A} 5$ are $\mathrm{pH} 7.0$ and $28-35^{\circ} \mathrm{C}$, respectively. The strain was able to degrade $96 \%$ of the initial $100 \mathrm{mg} \mathrm{l}^{-1}$ aniline and grow at the aniline concentration of as high as $700 \mathrm{mg} \mathrm{l}^{-1}$. The current study indicates that these strains, particularly $E$. ludwigii KH-A5, would prove to be a promising candidate for bioremediation of aniline contaminated sites.

\section{References}

Ahmed S., Ahmed S., Farrukh Nisar M., Hussain K., Majeed A., Ghumroo P.B., Afghan S., Shahzad A., Nawaz K. and Ali K. (2010), Isolation and characterization of a bacterial strain for aniline degradation, Afr J Biotechnol, 9(8), 1173-1179.

Ahmed Y.M., Kumosani T.A. and Sabir J.S.M. (2013), Bioremediation of 3,5-dinitrobenzoic acid and aniline by a Corynebacterium sp., Afr J Microbiol Res, 7(37), 4582-4589.

Aoki K., Ohtsuka K., Shinke R. and Nishira H. (1983), Isolation of aniline-assimilating bacteria and physiological characterization of aniline biodegradation in Rhodococcus erythropolis AN-13, Agric Biol Chem, 47(11), 2569-2575.

Arora P.K. (2015), Bacterial degradation of monocyclic aromatic amines, Front Microbiol, 6:820.

Bathe S. (2004), Conjugal transfer of plasmid pNB2 to activated sludge bacteria leads to 3-chloroaniline degradation in enrichment cultures, Lett Appl Microbiol, 38(6), 527-531.

Fujii T., Takeo M. and Maeda Y. (1997), Plasmid-encoded genes specifying aniline oxidation from Acinetobacter sp. strain YAA, Microbiology, 143: 93-99.

Fukumori F. and Saint C.P. (1997), Nucleotide sequences and regulational analysis of genes involved in conversion of aniline to catechol in Pseudomonas putida UCC22 (pTDN1), J Bacteriol, 179(2), 399-408. 
Holt G.J., Krieg R.N., Sneath A.H.P., Staley T.J. and Williams T.S. (1994), Bergey's manual of determinative bacteriology; 9th ed. Baltimore, USA: Williams and Wilkins Co.

Jian L. and Chunjuan X. (2007), Study on aerobic co-metabolism biodegradation of aniline in wastewater, Chinese J Environ Eng, 1(6), 51-55.

Kafilzadeh F., Avatefi Nejad R. and Mahmoodi Nejad F. (2013), Isolation and identification of aniline degrading bacteria from sediments of Kharg island in Persian Gulf, European Journal of Experimental Biology, 3(3), 454-460.

Kafilzadeh F. and Farhadi N. (2015), Molecular identification and resistance investigation of atrazine degrading bacteria in the sediments of Karun river, Ahvaz, Iran, Microbiology, 84(4), 531-537.

Li J., Jin Z. and Yu B. (2010), Isolation and characterization of aniline degradation slightly halophilic bacterium, Erwinia sp. strain HAS 6, Microbiol Res, 165(5), 418-426.

Li W., Barrington S. and Kim J. (2007), Biodegradation of pentyl amine and aniline from petrochemical wastewater, J Environ Manage, 83(2), 191-197.

Liang Q., Takeo M., Chen M., Zhang W., Yu X. and Lin M. (2005), Chromosome-encoded gene cluster for the metabolic pathway that converts aniline to TCA-cycle intermediates in Delftia tsuruhatensis AD9, Microbiology, 151, 3435-3446.

Liu Z., Yang H., Huang Z., Zhou P. and Liu S.J. (2002), Degradation of aniline by newly isolated, extremely aniline-tolerant Delftia sp. AN3, Appl Microbiol Biotechnol, 58, 679-682.

Maurice C.F., Haiser H.J. and Turnbaugh P.J. (2013), Xenobiotics shape the physiology and gene expression of the active human gut microbiome, Cell, 152(1-2), 39-50.

Meyers N.L. (1999), Molecular cloning and partial characterization of the pathway for aniline degradation in Pseudomonas sp. strain CIT1, Curr Microbiol, 24(6), 303-310.

Mohammed M., Ch S. and Ch R.V. (2014) Aniline is an inducer, and not a precursor, for indole derivatives in Rubrivivax benzoatilyticus JA2, PLOS ONE, 9(2), 1-10.

Murakumi S., Takashima A., Takemoto J., Takenaka S., Shinke R. and Aoki K. (1992), Cloning and sequence analysis of two catechol-degrading gene clusters from the aniline assimilating bacterium Frateuria species ANA-18, Gene, 226(2), 189-198.

Obinna C.N., Shalom N.C. and Olukayode O.A. (2008), Biodegradation potential of two Rhodococcus strains capable of utilizing aniline as carbon source in a tropical ecosystem, Res. J Microbiol, 3(2), 99-104.

O'Neill F.J., Bromley-Challenor C.A., Greenwood R.J. and Knapp J.S. (2000), Bacterial growth on aniline: implications for the biotreatment of industrial wastewater, Water Res, 34(18), 4397-409.

Recommendation from the Scientific Committee on Occupational Exposure Limits for aniline, SCOEL/SUM/153. The European Commission, Employment Social Affairs and Inclusion. August 2010.

Sarwade V. and Gawai K (2014) Biodegradation of aniline by alkaliphilic strain Bacillus badius D1., IOSR J Environ Sci Toxicol Food Technol, 8(5), 71-78.

Sihtmae M., Mortimer M., Kahru A. and Blinova I. (2010), Toxicity of five aniline to crustaceans, protozoa and bacteria, J Serb Chem Soc, 75(9), 1291-1302.

Suzuki M.T. and Giovannoni S.J. (1996), Bias caused by template annealing in the amplification of mixtures of $16 \mathrm{~S}$ rRNA genes by PCR, Appl Environ Microbiol, 62, 625-30.

Takeo M., Fujii T., Takenaka K. and Maeda Y. (1998), Cloning and sequencing of a gene cluster for the meta-cleavage pathway of aniline degradation in Acinetobacter sp. strain YAA, J Ferment Bioeng, 85(5), 514-517.

Wang D., Zheng G., Wang S., Zhang D. and Zhou L. (2011), Biodegradation of aniline by Candida tropicalis AN1 isolated from aerobic granular sludge, J Environ Sci, 23(12), 2063-2068.

Wang L., Barrington S. and Kim J.W. (2007), Biodegradation of pentyl amine and aniline from petrochemical wastewater, J Environ Manage, 83(2), 191-197.

Weaver R.W., Angle S., Bottomley P., Bezdicek D., Smith S., Tabatabai A. and Wollum A. (1994), Methods of Soil Analysis. Part 2: Microbiological and Biochemical Properties. Soil Science Society of America, Inc. 
Xiao C., Ning J., Yan H., Sun X. and Hu J. (2009), Biodegradation of aniline by a newly isolated Delftia sp. XYJ6, Chinese J Chem Eng, 17(3), 500-505.

Yen J.H., Tsai P.W., Chen W.C. and Wang Y.S. (2008), Fate of aniline and aniline herbicides in plant-materials-amended soils, J Environ Sci Health B, 43, 382-389.

Zhang T., Zhang J.L., Liu S.J. and Liu Z.P. (2008), A novel and complete gene cluster involved in the degradation of aniline by Delftia sp. AN3, J Environ Sci, 20(6), 717-724.

Zissi U.S., Lyberators G.C. and Pavlou S. (1997), Biodegradation of paminoazobenzene by Bacillus subtillis under aerobic conditions, J Ind Microbiol Biotechnol, 19, 49-55. 